\title{
A Marketing Approach to Commodity Futures Exchanges: A Case Study of the Dutch Hog Industry
}

\section{Matthew T. G. Meulenberg and Joost M. E. Pennings*}

(Original received December 1999; Revision received May 2001; Accepted December 2001)

This paper proposes a marketing strategic approach to commodity futures exchanges to optimise the (hedging) services offered. First, the environment of commodity futures exchanges is examined. Second, the threats and opportunities of commodity futures exchanges are analysed. Our analysis demonstrates that market orientation is an important element in the market strategies of commodity futures exchanges. Our market strategic framework is applied to the Dutch hog futures market. It is concluded that market penetration is an appropriate strategy. Consequently, to identify the variables that distinguish between farmers who initiate futures positions and farmers who do not, we conducted a discriminant analysis on data gathered from 418 Dutch hog farmers. The discriminant analysis shows that latent variables, such as farmers' perceived performance, farmers' reference price and farmers' market orientation, are important discriminating variables. Furthermore, farmers' cash market behaviour (in terms of the frequency of selling in the spot market) is an important discriminating variable as well. The usefulness of these results as input for a penetration policy is demonstrated.

\section{Introduction}

In the literature, much attention has been paid to valuation models for commodity futures and the efficient functioning of commodity futures exchanges (CFEs) (e.g. Ederington, 1979; Kellard et al., 1999). These models indicate how hedgers should compose their portfolios; that is, which type of futures contract should be used and how many. Géczy, Minton and Schrand (1997) and Koski and Pontiff (1999), amongst others, show that these models fail to describe the behaviour of hedgers towards futures contracts. Moreover, these models provide limited insight into how to improve the services offered by CFEs, in order to generate more volume and liquidity in the markets. In this paper, we try to bridge this gap, focussing on agricultural CFEs as a mechanism offering price risk services. We find that successful CFEs need to develop a marketing strategy consisting of a mission statement, an analysis of the general environment, an evaluation of the opportunities and threats and an assessment of the strengths and weaknesses of the CFE compared to its competitors. In addition, CFEs require a marketing strategy that may be operationalised in annual marketing programs (see, for example, Jain (1997); Walker, Boyd and Larréché (1992)).

\footnotetext{
* Matthew Meulenberg is at Wageningen University, Department of Marketing \& Consumer Behaviour, Hollandseweg 1, $6706 \mathrm{KN}$ Wageningen, The Netherlands. Joost Pennings is from the University of Illinois at Urbana-Champaign, Department of Agricultural \& Consumer Economics, 326 Mumford Hall, MC-710, 1301 West Gregory Drive, Urbana, IL 61801, USA. E-mail: jmpennin@uiuc.edu for correspondence. Financial support provided by Euronext-Amsterdam, de Algemene Stichting Termijnhandel (AST), Chicago Mercantile Exchange, Foundation for Research in Agricultural Derivatives, the Office for Futures and Options Research, and the Niels Stensen Foundation is gratefully acknowledged.
} 
CFEs that take a marketing approach are not only reactive to the needs of traditional clients, but also pro-active in developing new services for existing and potential customers. In traditional finance, hedgers' actions are guided by the criterion of maximizing expected utility; non-economic factors do not enter their utility function. Behavioural finance takes the position that not all decisions can be described by the equilibrium conditions in an economy. Thaler (1993) states that: "sometimes, in order to find the solution to an empirical puzzle, it is necessary to entertain the possibility that some of the agents in the economy behave less than fully rational some of the time". Some concepts used by (potential) hedgers are psychological constructs (e.g. "level of understanding") that are not directly measurable and therefore remain absent in accounting data. These constructs, however, may very well play a part in the (potential) hedger's decision behaviour. In line with DeBondt and Thaler (1995), we believe that good finance theory is to be grounded on evidence about people's actual behaviour. It has been argued that behaviour can be characterised by a decision process, driven by perceptions and attitudes (McFadden, 1999).

Using this framework we will analyse the position of CFEs in general and then focus on the Dutch Hog Futures Market to illustrate the usefulness of a market strategic approach to futures marketing. We shift the perspective from portfolios to the management of agricultural CFEs, whose mission is: "to offer agro-food businesses price risk management services (hedging services) and the public at large an opportunity to generate income from spatial and temporal arbitrage (speculating services)". Taking a market strategic approach to agricultural futures exchanges, the environment of CFEs is analysed in section 2. Subsequently, in section 3 the market position of CFEs is discussed, borrowing the concepts from SWOT analysis. Market opportunities not only depend on the price risk reduction needs of agricultural enterprises and agribusiness companies, but also on the strategic response of CFEs to these needs. Alternative strategic responses, amongst others segmentation (specific services to specific target markets) and improving quality (low trading risk and efficient clearing), are reviewed in section 4. The proposed market strategic framework is applied to the Dutch Hog Futures Market in section 5. A concise analysis of the Dutch Hog Futures Exchange leads to the conclusion that market penetration might be an attractive strategy. Farmers' decisionmaking processes are analysed in order to gain insight into the factors influencing the use of futures. In line with Brorsen and Irwin (1996), who argued that more work is needed using primary data on hedging activity, we examine the relationship between farmers' characteristics and their use of futures, based on a large-scale interview. We conduct a discriminant analysis to identify the variables that distinguish between farmers who initiate futures positions and farmers who do not. Section 5 concludes with the marketing-strategic implications of our empirical findings. The paper ends with suggestions for further research in section 6 .

\section{Developments in the Environment of Commodity Futures Exchanges}

CFEs operate in a task environment, directly relevant for fulfilling the mission at a profit. The main players of the task environment are customers, competitors, government and lobby groups. The task environment is embedded in a general environment, traditionally categorised in the political, economic, social, technological and physical environment. Trends in the task environment and general environment 
offer challenges and opportunities to CFEs. Marketing policies require adapting to environmental changes, both to respond timely to market challenges and to create new market opportunities. We will briefly discuss major environmental trends relevant to CFEs.

\section{Developments in the Task Environment}

\section{Development of Customers}

The potential users of price risk reduction services for agricultural commodities can be differentiated on the basis of two dimensions, the type of actor in the marketing system and the type of product hedged by that actor. On the one hand, different actors in the agricultural-food marketing system can use a CFE to reduce price risks related to the product underlying the futures contract. On the other hand, trading futures contracts can also alleviate price risks of related products (i.e. cross hedging) (e.g. Rolfo, 1980). In fact all substitutes whose prices are strongly correlated to the price of the product underlying a futures contract are suitable for cross hedging (Pennings and Leuthold, 2001a). Therefore, market opportunities for commodity futures contracts depend on developments among both actors and products of agricultural food marketing systems. This section discusses the developments among actors and products in Agricultural-food Marketing Systems that influence the market opportunities for futures contracts.

\section{Developments among Actors in Agricultural-food Marketing Systems}

Basic trends among actors in agricultural food marketing systems (suppliers, producers, traders and processors) are specialisation (focusing on core competencies), concentration (larger companies), and vertical co-ordination (chain management) (see Wierenga et al., 1997; Messinger and Narasimhan, 1995). As a result, agricultural food systems evolve towards larger companies, whose turnover depends on a smaller number of products and, as such, become more sensitive to price volatility. The increased price risk makes CFEs a more attractive option.

Another development is the increasing importance of free-trade areas, such as NAFTA, EU and MERCOSUR, which create increasingly homogeneous regions in terms of economic, agricultural and monetary policies. For instance, the number of farms and processing industries in the European Union (EU) will increase due to the entry of Middle and East European countries. Actually, the four largest producers in Europe (Great Britain, France, Germany and Poland) produce about 12 per cent of the world production of wheat, 18 per cent of the production of barley, 18 per cent of the production of potatoes, and 11 per cent of the production of pork, about equalling the production of the US (Pennings, Rembeza and Link, 1998).

The size of agribusiness companies, such as mixed feed industries and trading companies, is increasing. These large companies might become more interested in futures trading because of (a) efficient purchases of raw materials that contribute substantially to their profitability and (b) stronger commitment to their shareholders, thereby increasing the importance of stable growth in income and profits.

A barrier to the market opportunities of CFEs is the lack of knowledge among potential hedgers. Some, particularly farmers and small or medium-sized processing industries, consider using a CFE gambling rather than rational economic behaviour. Regional differences occur in this respect: US farmers seem more knowledgeable and 
familiar with CFEs than farmers elsewhere. CFEs not only serve hedgers of a specific commodity, but also people who aim to decrease risks on investments in general, by taking a position in commodity futures. At present, to have a minor portion of commodity futures in one's derivatives-portfolio is common practice to offset financial risks in investments and assets (Brorsen and Lukac, 1990).

\section{Developments in the Types of Product Hedged}

Developments in farms and agribusinesses influence the quantity and quality of agricultural and food products and, therewith, the need for price risk reduction services. A more homogeneous product supply from large specialised farms may stimulate the demand for CFEs' price reduction services. Segmentation and product differentiation by agricultural-food marketing systems enhance heterogeneity in agricultural product supply, thereby increasing the need for cross hedging (Pennings and Leuthold, 2000b).

\section{Competitors}

CFEs have many competitors providing price risk reduction:

i) Over the Counter Trading (OTC): large agribusiness companies and banks often facilitate this practice in commodity trading.

ii) Cash forward trading: still one of the most important ways of reducing price risk for farmers.

Specific marketing behaviour of farmers may also compete with CFE-services:

i) Marketing channel choice (risky versus safe): usually, a farmer has the opportunity to sell his output through different marketing channels that differ in the price risk they generate, such as: trader, wholesaler, co-operative, or directly to the consumer. Choice of marketing channel, therefore, can be a risk reduction strategy.

ii) Frequency of trading: a farmer can reduce price risk by frequently selling a part of his total production. Selling one's output all at once at the spot market price would be risky. Spreading sales by trading frequently yields an average price. This strategy is very attractive to highly risk-averse managers, since it allows for substantial price risk reduction (Pennings and Smidts, 2000; Pennings and Garcia, 2001).

iii) Co-ordination of company policies: price risks in agricultural-food marketing systems are often reduced by co-ordination policies. They include sharing price risks between companies or transferring the price risk reduction function to the company that best handles price risks. However, many agricultural food marketing systems do not include prices in contractual agreements and leave price risks to the individual companies. The primary co-operative offers some sort of price risk reduction, in that it pools the product prices of its members (Smidts, 1997). However even co-operatives increasingly differentiate product prices, based on market developments and quality differences.

\section{Governments}

Agricultural markets open up due to the WTO negotiations and related developments such as in the EU, where the CAP shifts from supporting farm prices towards income support to farmers. Also the introduction of the Euro will enhance open agricultural 
markets and facilitate hedging within the EU, as currency risks will disappear for EU farmers and agribusiness companies, who hedge at CFEs located in the Euro-countries. The Euro might also facilitate speculative transactions on EU futures markets. Government policies therefore have a great impact on the market opportunities of CFEs. Actually, in some countries, for example Germany, governments have become more favourable towards CFEs. ${ }^{1}$

\section{Lobby Groups}

Farmers' unions make a relevant lobby group for CFEs. In various countries farmers are unknowledgeable and sometimes even suspicious, about CFEs. This negative attitude is changing in Western European countries, such as Germany and Netherlands, since farmers are becoming more aware of the need for price risk insurance. They are increasingly curious about the role of CFEs.

\section{Some Trends in the General Environment of CFEs}

Trends in the general environment of CFEs create market opportunities through the task environment of CFEs that have been discussed. Technological and physical trends also have an important direct influence on CFEs. Therefore, attention will be paid to developments in these components of the general environment.

\section{Developments in the Technological Environment}

Technological developments, particularly in the field of information technology, enhance the speed of operations and lower the costs of doing business. Various futures markets, especially in financial derivatives, are fully computerised: the Chicago Board of Trade's (CBOT) Project A exemplifies electronic commodity futures trading. CBOT combines project A with open outcry. The Warenterminbörse in Hanover is the only fully electronic CFE in the world. Futures exchanges will probably increase efficiency and improve their ease of use with new information technologies.

\section{Developments in the Physical Environment}

The degradation of air, water, and land as a result of the production and marketing methods used is an important issue for agricultural-food marketing systems. Ecological concern in society leads to government regulations to protect the physical environment. These measures do not seem to have a direct influence on the market potential of CFEs. However, in countries like the United States, where tradable environmental rights have been introduced, opportunities emerge for a futures trade in these rights. Moreover, farmers and agribusiness companies have been affected by policies that involve production rights. Pennings and Meulenberg (1998) showed that rights futures have some features that make them effective and efficient tools for managing price risk. Futures trade in rights is still of limited importance.

\section{The Market Position of CFEs from a Strategic Perspective}

CFEs base their market strategies on their strengths and weaknesses compared to other price risk management institutions and procedures, on the opportunities and threats, respectively, which emanate from environmental trends. These topics are well-known elements of a SWOT-analysis. While we do not perform a SWOT-analysis in the strict

\footnotetext{
${ }^{1}$ In 1994, Germany introduced a law that reinstates commodity futures trade (2. Finanzmarktfoerderungsgesetz).
} 
sense, we borrow its concepts in the following evaluation of the market position of CFEs as a price risk management institution.

\section{Strengths of Commodity Futures Exchanges}

The strengths of a CFE as a price risk reduction provider are:

i) Availability: every company able to fulfil the margin requirements can hedge price risks for a specific commodity.

ii) Flexibility: hedging operations can start and close at any time, to the discretion of the hedger.

iii) Objectivity: exactly because they are open spot markets, CFEs offer an "objective" and up-to-date picture of actual and future price developments.

\section{Weaknesses of Commodity Futures Exchanges}

The weaknesses of CFEs as a company offering price risk reduction services are:

i) Trading risk (hedging risk): A hedger is substituting price risks for hedging risks. Important hedging risks are:

a) basis risk might increase because of more product differentiation, resulting in cross-hedging (e.g. Castelino, Francis and Wolf, 1991).

b) market depth risk is particularly felt at small CFEs. It may decrease with larger CFEs (e.g. Pennings et al., 1998). In some regions, specific developments help decrease market depth risk, e.g. the introduction of the Euro in the EU.

c) lumpiness: farmers cannot specify the amount to be hedged to correspond to the quantity they have available for sale. Thus, a futures hedge may not exactly match the amount of the desired sale or purchase. Lumpiness causes a proportion of the cash position to remain exposed to uncertain changes in price. Note that if the quantity to be hedged increases, the relative importance of lumpiness declines and ultimately approaches zero.

d) margin cost risk: a buyer/seller of a futures contract must put an initial margin and, depending on price developments, a maintenance margin. These are additional interest costs of hedging by futures trading. Kalavathi and Shanker (1991) show that increasing margin costs cause lower hedger demand for futures contracts.

ii) Negative image. Various potential users of CFE-services have a negative attitude towards futures trading, which they perceive as gambling instead of rational economic business. ${ }^{2}$ While in the past "corners" have contributed to the poor image of CFEs, this weakness seems to be decreasing thanks to regulations that enhance the economic function of futures markets. We may expect the image of CFEs to improve, as entrepreneurship in farming and the agro-food industry increases.

iii) Non-feasibility of products for futures trade. Futures contracts are available for a large number of agricultural commodities. However, for many agricultural commodities, such as fresh horticultural products, no viable futures trade is possible. This limits the potential market for CFEs.

${ }^{2}$ Ennew, Morgan and Rayner (1992a, 1992b) showed that actual and potential users are heavily influenced by their subjective assessments of the performance and reliability of a futures market. 


\section{Opportunities for Commodity Futures Exchanges}

Our analysis of the CFE environment suggests that market potential for futures trade is increasing. Amongst others, a more rational type of farming offers more opportunities for hedging services. Farmers not only become more interested in price risk reduction, they are also less inclined to reduce price risks by collective action, e.g. joining cooperatives. Also agribusiness companies become more interested in futures in order to avoid extreme ups and downs in financial results. Managers of companies with shareholders are replacing their criteria of performance, such as market share and sales growth, with new ones that judge market strategies by their ability to enhance shareholder value (Srivastava, Shervani and Fahey, 1998; Doyle, P., 2000). Srivastava, Shervani and Fahey (1998) argued that reducing cash flow volatility contributes to shareholder value, as reduced volatility in cash flow results in lower costs of capital or discount rates, which in its turn produces higher net present values and, hence, more shareholder value. Therefore, managers of agribusiness companies that issue shares have to take risk into account, and will be inclined to use futures contracts to reduce price risk.

\section{Threats to Commodity Futures Exchanges}

Due to specific marketing policies (e.g., product differentiation and market segmentation) the co-ordination of activities in agricultural-food marketing systems is increasing, including fixed price contract, minimum-price contract, or a formula for profit sharing. It alleviates the price risks of companies in the channel and consequently decreases a company's need for hedging. A threat to CFEs in some regions, e.g. Europe, is their small size, which inhibits the volume growth of futures contracts. The national orientation of CFEs contributes to this situation.

\section{Strategies of Commodity Futures Exchanges}

After an analysis of the marketing environment and the market position of CFEs, the contribution of "classic" marketing strategies to exploiting available market opportunities will be discussed. First it must be noticed that futures trade is based on the integrated services of floor, clearing house and members. The CFE is responsible for the floor operation, but has to include in its strategy the policies and opinions of both clearing house and members. In some instances, e.g., margin management, the services of the Clearing House play a dominant role in the marketing strategy.

\section{Market Penetration}

There seems ample room for market expansion of existing futures contracts among customers already familiar with CFEs. Further market penetration requires different communication policies towards specific target markets, for example hog farmers and the meat-packing industry.

\section{Focus: Specific Products for Specific Target Markets}

Essentially, CFEs are markets trading a standardised product, a futures contract. However, when customers differ enough, CFEs might consider developing specific price risk services for specific target groups. Some criteria for distinguishing specific target groups are: differences in price risk, farmers' and agribusiness managers' attitudes 
towards price risks, and familiarity with futures markets. For instance, a producer of different potato varieties cannot completely hedge price risks when only one potato futures contract is offered and cross hedging cannot cover all price risks. Moreover, while strongly risk-averse customers hedge systematically, slightly risk-averse customers might prefer options on futures for excluding negative price fluctuations.

\section{Differentiation by Quality}

The quality of services offered by CFEs can be increased by: (a) minimising basis risk through effective contract specification and efficient delivery, (b) minimising market depth risks through an order book mechanism that allows potential participants to view real time limit orders, displaying the desired prices and quantities at which participants wish to trade, (c) developing margin policies which guarantee fulfilment of contracts and (d) improving the ease of using futures, e.g. electronic marketing.

\section{Low Cost Services}

Efficiency and a related low commission may give a CFE a competitive edge, if the hedging service fits the customers' price risk reduction needs. Recently the Deutsche Terminbörse (DTB) took over the Bund Futures traded at LIFFE (London). DTB took the largest share of the volume by allowing Bund futures to be traded at extremely low transaction costs. With the advent of the Euro, a potential hedger can choose more easily between different CFEs in the EU. Differences in costs may then cause increased competition between CFEs.

\section{Innovation, Development of New Services}

Innovation is an aspect of many of the above strategies. It can be focused on stimulating the demand of existing customers, but also on attracting new customers. Many innovations have been introduced by CFEs in order to exploit the market potential, namely: (a) futures on new products, e.g. on eggs; (b) a better specification of existing contracts conform changing market conditions, and (c) new services to futures contracts, e.g. options on futures.

\section{Market Orientation}

Market orientation is advocated as the basic strategy of any marketing organisation. It is also a basic strategy for marketing price risk reduction services. The concept was baptised by various marketing scholars, e.g. Kohli and Jaworski (1990) and Narver and Slater (1990). The former define market orientation as: “...the organisation-wide generation of market intelligence, pertaining to current and future customer needs, dissemination of the intelligence across departments, and organisation-wide responsiveness to it." (Jaworski and Kohli, 1993). Futures research usually takes a technical approach to determine the desirable characteristics of commodity futures, without taking market orientation into account. The technical approach defines commodities feasible for futures trade, based on an extensive list of required commodity attributes (Black, 1986). This approach has increased our insight into the technical factors that facilitate viable commodity futures trade (Black, 1986). Meeting these criteria, however, does not guarantee the market success of the services provided. Their success also depends on the extent to which these services meet the needs of (potential) customers at a competitive price. 


\section{An Application of the Market Strategy Approach to the Dutch Hog Futures Exchange}

The proposed market strategic framework will be illustrated by an application to the Dutch Hog Futures Exchange. A concise description of the Exchange, its environment, strengths and weaknesses, suggests that market penetration would be an appropriate strategy. Therefore the attitudes and decision-making of farmers and managers of agribusiness companies concerning futures trading are analysed in depth. On the basis of the research results, conclusions are drawn about strategy implementation.

\section{The Dutch Hog Futures Exchange}

Dutch hog futures contracts were introduced in 1980. At present it is a business unit of the Euronext, the merger between the exchanges of Amsterdam, Brussels and Paris. Futures contracts are specified in 10 ton slaughtered weight of pork per month. Costs per contract amount to about 1 per cent of the underlying value. The turnover of the Hog Futures Exchange is modest: 45,705 contracts in 1998 and 43,051 contracts in 1999. There is a need for turnover expansion and the CFE might wonder how to change its market strategy accordingly.

On the basis of the proposed market strategic framework, the following marketcharacteristics seem relevant for an expansion of the CFEs' turnover. Dutch pork production is substantial, 1,7 million tons in 1999. It is decreasing, due, amongst other reasons, to environmental problems with the manure surplus and related costs. The number of pig farms is decreasing while their size is increasing, from 362 pigs in 1995 to 504 pigs per farm in 2000 . Farmers supply a standard pig to the market, making cross hedging a minor issue. Special programs for animal-friendly production and free-range pigs are increasing but of minor importance so far. Few pig farmers are knowledgeable about the pros and cons of price risk reduction by hedging. Only a few foreign pig farmers operate at the Dutch futures exchange. Different breeds, different currencies, and small production size prevent foreign pig farmers from doing business at the Dutch Hog Futures Exchange. The introduction of the Euro will diminish barriers for EU pig farmers. However, in some other European countries, e.g., Germany, hog futures exchanges are in operation, whose underlying product suits the respective foreign pig farmers better. Other price risk reduction institutions, such as contract farming and cooperative membership, also compete with the Dutch Hog Futures Exchange. This competition seems of minor importance: 15 per cent of Dutch pig farmers were engaged in contract farming, mainly without guaranteed prices, sometimes with a minimum price scheme (Pennings and Smidts, 2000). Dutch pig co-operatives offer their members no guaranteed price, nor a pooled price. Given the limited market turnover, computerised trade seems too high an investment now. A specific weak point of the Dutch Hog Futures Exchange also seems market depth risk due to modest turnover (e.g., Pennings et al., 1998).

\section{Analysis of the Use of Futures by Farmers}

Basic Aspects and Assumptions

The foregoing description suggests that market penetration through better market/ customer orientation may be an appropriate strategy for the Dutch hog futures exchange. This particularly requires understanding of attitudes and farmers' decision-making 
about futures trading. Our analysis focuses on the influence of basic characteristics: risk attitude, risk perception, level of understanding futures trade, and farmers' market orientation concerning the decision to enter the futures market. Furthermore, we investigate how often a farmer enters the risky market, because selling frequently competes with futures trading as a risk reduction strategy. One might also expect farmers to consider the futures price level in their decision process. From the literature decision makers are known to use anchor points to evaluate a stimulus, in our case, futures prices (Payne, Laughhunn and Grum, 1980). We hypothesise that farmers compare the futures price level to their reference price (Tversky and Kahneman, 1981). The reference price is defined as the farmer's internal price that (s)he uses as an anchor to judge other prices. The further the futures price exceeds the farmer's reference price, the more attractive a futures position becomes, and vice versa.

\section{Survey and Experiment}

Personal computer-guided interviews were administered to 418 owner-managers. Each interview lasted for about 45 minutes. The farmers were contacted by the interviewer prior to the interview to encourage participation and to ensure that the right person would be interviewed. Farmers were confronted with statements measuring their market orientation, level of understanding and risk attitude (see Appendix for a detailed explanation of the scales). Furthermore, farmers had to indicate the perceived performance of futures markets on a three-item scale (see Appendix) and provide background information, such as age, farm size and the number of times hogs are sold in the cash market.

Confirmatory factor analysis was used to assess the (psychometric) measurement quality of our constructs (Steenkamp and van Trijp, 1991). All factor loadings were significant (minimum $t$-value was $4.60, \mathrm{p}<0.001$ ) and higher than 0.4 . These findings support the convergent validity of the items. The composite reliabilities for the constructs ranged from 0.70 to 0.76 , indicating good reliabilities for the construct measurements. Details regarding the psychometric properties are given in the Appendix.

The reference price was identified by using Puto's question format (1987). In this format, the respondent identifies, through an iterative process, the price above which profit is perceived and below which loss. The ratio of the futures price level to the reference price was calculated by dividing the price level of the futures contract by the manager's reference price. The nomological validity of the elicited reference price was tested by correlating the manager's reference price to the manager's cost of raising hogs, and, as expected, the correlation was significantly positive $(\rho=0.86, p=0.00)$, confirming the nomological validity of the measurement procedure to obtain the manager's reference price (Churchill, 1979).

Finally, the farmers were exposed to an experiment for deciding whether or not to initiate a futures position. In order to match the real decision situation of the subjects, we measured the farmer's behaviour in initiating a futures position using a scenario framework that closely matched the real business situation of our respondents. Validity of scenarios as a research tool appears to be high, particularly when subjects are required to "play themselves" rather than unfamiliar roles (Bem, 1967). During the measurement the farmers were instructed that "it is important to imagine yourself in the situation described". They were given a choice between selling their hogs forward through futures 
contracts or selling on the spot market. Five different futures price levels were randomly assigned to the managers in the survey. These price levels were based on futures market data from previous years and reflected the price distribution function. The managers perceived the scenario as very realistic.

\section{Results}

We use discriminant analysis to identify variables that distinguish farmers who initiate futures from farmers who do not. The discriminant analysis finds a linear combination of independent variables that forms the basis for classifying farmers into the two groups (for a detailed discussion on discriminant analysis see McLachlan, (1992)).

Table 1 Test of Equality of Group Means and Standardised Canonical Discriminant Function Coefficients

\begin{tabular}{lccc}
\hline Discriminating variables & Wilks' Lambda & Sig. & $\begin{array}{c}\text { Discriminant function } \\
\text { coefficients }\end{array}$ \\
\hline Frequency of trading in the risky market & 0.986 & 0.016 & -0.359 \\
Farmer's market orientation & 0.971 & 0.000 & 0.431 \\
Level of understanding futures markets & 0.983 & 0.007 & -0.367 \\
Perceived performance of futures & 0.981 & 0.004 & 0.397 \\
Ratio of futures price level and the farmer's & & & 0.000 \\
$\quad$ psychological reference price & 0.936 & 0.754 \\
\hline
\end{tabular}

* Please note that these variables are not correlated, and hence that the coefficients are stable.

Table 1 shows the linear combination of variables that present the discriminating function minimising the probability of misclassification. In order to come up with this optimal discriminating function we applied a stepwise procedure in which we tested for the contribution of variables to the discriminating power by Wilks' lambda statistic (see Hair et al., 1995). Table 1 shows that the means of the variables included in the discriminant function significantly differed across the two groups (farmers who initiate a futures position and farmers who do not)

Table 2. Classification Results of Discriminant Analysis

\begin{tabular}{|c|c|c|c|c|}
\hline & \multirow[b]{2}{*}{ Choice: futures or not? } & \multicolumn{2}{|c|}{ Predicted Group Membership } & \multirow[b]{2}{*}{ Total } \\
\hline & & Futures & No futures & \\
\hline \multicolumn{5}{|l|}{ Original $^{\mathrm{a}}$} \\
\hline \multirow[t]{2}{*}{ Count } & Futures & 71 & 34 & 105 \\
\hline & No futures & 14 & 299 & 313 \\
\hline \multirow[t]{2}{*}{$\%$} & Futures & 77.0 & 33.0 & 00.0 \\
\hline & No futures & 4.5 & 95.5 & 00.0 \\
\hline \multicolumn{5}{|c|}{ Cross-validated $^{\mathrm{b}}$} \\
\hline \multirow[t]{2}{*}{ Count } & Futures & 71 & 34 & 105 \\
\hline & No futures & 16 & 297 & 313 \\
\hline \multirow[t]{2}{*}{$\%$} & Futures & 77.0 & 33.0 & 00.0 \\
\hline & No futures & 5.1 & 94.9 & 00.0 \\
\hline
\end{tabular}

a 88.5 per cent of original grouped farmers correctly classified.

b 88.0 per cent of cross-validated grouped farmers correctly classified.

The canonical correlation of the discriminant function was $0.485(p=0.000)$, showing a strong association between the discriminant scores and the two groups. Using the 
discriminant scores, a rule can be obtained for classifying farmers into one of the two groups. Bayes's rule was used in this paper (e.g. McLachlan, 1992). Table 2 shows the predictive power of the discriminant function. To obtain non-biased insight into the discriminating power of our function, we used the jack-knife method. This method leaves out each of the farmers in turn, and then calculates the function based on the remaining $n$ - 1 farmers and afterwards classifies the left-out farmer. 88 per cent of farmers grouped by cross-validation were correctly classified, indicating a good predictive validity of the variables in the discriminant function.

Our analysis shows that the frequency of entering the (risky) cash market, farmers' market orientation, level of understanding, farmers' perceived performance and the difference between the farmers reference price and futures price are variables that are able to distinguish between the two groups of farmers. Interestingly, risk attitude did not help discriminate between two groups, a finding confirmed in previous research (Goodwin and Schroeder, 1994). Our analysis shows that demographic variables are unable to discriminate between farmers who choose to use futures and farmers who do not. In line with the findings of Ennew, Morgan and Rayner (1992b), our analysis shows that several variables that are not directly observable are important in discriminating between two groups. The level of understanding is an important variable to discriminate between the two groups. The farmers' reference price in relation to futures price level is a discriminating variable too. The farmers in our sample showed heterogeneity in their reference price. Hence, the attractiveness of a particular futures market price level is not equal across farmers. Hog farmers who enter the risky market by selling relatively often in the cash market have no need to hedge the risk in the futures market, since their frequent sales constitute a marketing strategy which produces an average price and hence reduces the need for risk management through futures contracts. Farmers that are market-oriented are more inclined to enter the futures market. They put a lot of effort into marketing their products and perceive futures as vital for their farm operation.

\section{Implications for CFE Market Strategy}

CFEs should realise market penetration through communication and education in order to (a) make farmers aware of the risk reduction potential of futures; and (b) make farmers more knowledgeable about the pros and cons of future trading, thereby lowering the costs of education in futures use. The communication and innovation strategies should be reinforced by improving market accessibility, respectively by internationalisation and/or merger. Since farmers' perceived performance of CFEs plays an important role in the decision about futures contracts, accurate real-time exchange information is attractive. The difference between the futures price and the reference price of the ownermanager appears to be a discriminating variable. Although the futures exchange cannot influence these two prices, it can profit from them when introducing new futures contracts.

\section{Suggestions for Future Research. General Conclusion and Suggestions for Future Research}

The strategic framework for CFEs proposed and empirically elaborated seems useful for positioning CFEs as providers of price risk reduction services. While useful for any $\mathrm{CFE}$, it is particularly relevant to small CFEs in the take-off stage. Further insight is 
needed into farmers' risk management alternatives. The risk management services offered by CFEs may serve as substitutes for vertical integration and influence the channel choice (risky versus safe). The interdependency between channel members regarding their risk management behaviour would be an interesting avenue to explore in the future. In order to identify the customer segments with respect to futures contracts usage, procedures must be developed that simultaneously identify the determinants of futures usage and the segments based on these determinants. The use of generalised mixture regression model seems interesting in this respect (e.g., Wedel and DeSarbo, 1995). This approach tells the futures exchange how different types of customers behave differently in similar situations. Moreover, this methodology can be a powerful tool for designing customised futures contracts. The multi-attribute attitude theory of Fishbein and Ajzen (1975), assuming attitudes to be decomposable as a sum of the products of beliefs and evaluations, might be an interesting avenue to explore when investigating farmers' attitude towards futures and their choice decision for or against futures.

\section{References}

Bem, D. J. (1967). Self Perception: An Alternative Interpretation of Cognitive Phenomena, Psychological Review, 74, 183-200.

Black, D. G. (1986). Success and Failure of Futures Contracts: Theory and Empirical Evidence, Monograph 1986-1 Salomon Brothers Center for the Study of Financial Institutions, New York.

Brorsen, B. W. and Irwin, S. H. (1996). Improving the Relevance of Research on Price Forecasting and Marketing Strategies, Agricultural and Resource Economics Review, 25, 68-75.

Brorsen, B. W. and Lukac, L. P. (1990). Optimal Portfolios for Commodity Futures Funds, Journal of Futures Markets, 10, 247-258.

Browne, M.W., and Cudeck, R. (1986). Single Sample Cross-Validation Indices for Covariance Structures. Multivariate Behavioral Research, 24, 445-455.

Castelino, M. G., Francis, J. C. and Wolf, A. (1991). Cross-Hedging Basis Risk and Choice of the Optimal Hedging Vehicle, Financial Review, 26, 179-210.

Churchill, G. A. (1979). A Paradigm for Developing Better Measures of Marketing Constructs, Journal of Marketing Research, 16, 64-73.

DeBondt, W. F. M. and Thaler, R. H. (1995). Financial Decision-making in Markets and Firms: A Behavioral Perspective, in Jarrow, Robert A., Maksimovic, Voijslav and Ziemba, William T. (eds.). Finance, Handbooks in Operations Research and Management Science 9, North Holland, Amsterdam, 385-410.

Doyle, P. (2000). Value-Based Marketing, John Wiley \& Sons, Ltd.., Chichester.

Ederington, L. H. (1979). The Hedging Performance of the New Futures Markets, Journal of Finance, 34, 157-170.

Ennew, T. C., Morgan, W. and Rayner, T. (1992a). Role of Attitudes in the Decision to Use Futures Markets: The Case of the London Potato Futures Market, Agribusiness: An International Journal, 8, 561-573.

Ennew, T. C., Morgan, W. and Rayner, T. (1992b). Objective and Subjective Influences on the Decision to Trade on the London Potato Futures Market, Journal of Agricultural Economics, 43, 160-174.

Fishbein, M., and Ajzen, I. (1975). Belief, Attitude, Intention, Behavior: An Introduction to Theory and Research. Reading, MA: Addison-Wesley.

Géczy, C., Minton, B. A. and Schrand, C. (1997). Why Firms Use Currency Derivatives, Journalof Finance, 52, 1323-1354.

Goodwin, B. K. and Schroeder, T. C. (1994). Human Capital, Producer Education Programs, and the Adoption of Forward Pricing Methods, American Journal of Agricultural Economics, 76, 936-947.

Hair, J. F., Anderson, R. E., Tanham, R. L. and Black, W. C. (1995). Multivariate Data Analysis, Prentice Hall, Inc., New Jersey.

Jain, S. C. (1997). Marketing Planning and Strategy, 5th ed., South-Western Publishing Co., Cincinnati.

Jaworski, B. J. and Kohli, A. K. (1993). Market Orientation: Antecedents and Consequences, Journal of Marketing, 57, 53-70.

Kalavathi, L. and Shanker, L. (1991). Margin Requirements and the Demand for Futures Contracts, Journal of Futures Markets, 11, 213-237. 
Kellard, N., Newbold, P., Rayner, T. and Ennew, C. (1999). The Relative Efficiency of Commodity Futures Markets, Journal of Futures Markets, 19, 413-432.

Kohli, A. K. and Jaworski, B. J. (1990). Market Orientation: The Construct, Research Proposition, and Managerial Implications, Journal of Marketing, 54, 1-18.

Koski, J. L. and Pontiff, J. (1999). How Are Derivatives Used? Evidence from the Mutual Fund Industry, Journal of Finance, 54, 791-816.

McLachlan, G. J. (1992). Discriminant Analysis and Statistical Pattern Recognition, Wiley Series in Probability and Mathematical Statistics, New York.

McFadden, D. (1999). Rationality for Economists?, Journal of Risk and Uncertainty, 19, 73-105.

Messinger,P. R. and Narasimhan, C. (1995). Has power Shifted in the Grocery Channel? Marketing Science, 14 (Spring), 189-223.

Narver, J. C. and Slater, S. F. (1990). The Effect of a Market Orientation on Business Profitability, Journal of Marketing, 54, 20-35.

Payne, J. W., Laughhunn, D. J. and Grum, R. (1980). Translation of Gambles and Aspiration Level Effects in Risky Choices Behavior, Management Science, 26, 1039-1060.

Pennings, J. M. E. and Garcia, P. (2001). Measuring Producers' Risk Preferences: A Global Risk Attitude Construct, American Journal of Agricultural Economics, 83, 993-1009

Pennings, J. M. E. and Leuthold, R. M. (2001a). Introducing New Futures Contracts: Reinforcement versus Cannibalism, Journal of International Money \& Finance, 20, 659-675

Pennings, J. M. E. and Leuthold, R. M. (2000b). The Role of Farmers' Behavioral Attitudes and Heterogeneity in Futures Contracts Usage, American Journal of Agricultural Economics, 82, 908-919.

Pennings, J. M. E. and Smidts, A. (2000). Assessing the Construct Validity of Risk Attitude, Management Science, 46, 1337-1348.

Pennings, J. M. E. (1998). The Market for Hedging Services: A Marketing-Finance Approach, Mansholt Studies, Wageningen, The Netherlands.

Pennings, J. M. E. and Meulenberg, M. T. G. (1998). New Futures Markets in Agricultural Production Rights: Possibilities and Constraints for the Dutch and British Milkquota Markets, Journal of Agricultural Economics, 49, 50-66.

Pennings, J. M. E., Rembeza, J. and Link, P. (1998). Innovationen bei Agrarwirtschaftlichen Warenterminkontrakten in Europa, WAU working paper Marketing \& Consumer Behavior Group, Wageningen University, Wageningen.

Pennings, J. M. E., Kuiper, W. E., ter Hofstede, F. and Meulenberg, M. T. G. (1998). The Price Path Due to Order Imbalances: Evidence from the Amsterdam AgriculturalFutures Exchange, European Financial Management Journal, 4, 47-64.

Puto, C. P. (1987). The Framing of Buying Decisions, Journal of Consumer Research, 14, 301-315.

Rolfo, J. (1980). Optimal Hedging Under Price and Quantity Uncertainty: The Case of a Cocoa Producer. Journal of Political Economy, 88, 100-116.

Smidts, A. (1997). The Relationship between Risk Attitude and Strength of Preference: A Test of Intrinsic Risk Attitude. Management Science, 43, 357-370.

Srivastava, R. K., Shervani, T. A. and Fahey, L. (1998). Market-Based Assets and Shareholder Value: A Framework for Analysis. Journal of Marketing, 62, 2-18.

Steenkamp, J-B. E. M., and van Trijp H. C. M. (1991). The Use of LISREL in Validating Marketing Constructs, Internal Journal of Research in Marketing, 8, 283-299.

Thaler, R. H. (1993). Advances in Behavioral Finance, Russell Sage Foundation, New York.

Tversky, A. and Kahneman, D. (1981). The Framing of Decisions and the Psychology of Choice, Science, 211, 453-458.

Walker, O. C., Boyd, H. W. and Larréché, J.-C. (1992). Marketing Strategy, Planning and Implementation, Homewood (Il.), Boston, Mass.

Wedel, M. and DeSarbo, W. S. (1995). A Mixture Likelihood Approach for Generalized Linear Models, Journal of Classification, 12, 21-55.

Wierenga, B., van Tilburg, A., Grunert, K., Steenkamp, J. E. B. M. and Wedel, M. (eds.) (1997). Agricultural Marketing and Consumer Behavior in a Changing World, Kluwer Academic Publishers, Boston. 